\title{
PARD3 wt Allele
}

National Cancer Institute

\section{Source}

National Cancer Institute. PARD3 wt Allele. NCI Thesaurus. Code C125527.

Human PARD3 wild-type allele is located in the vicinity of 10p11.21 and is approximately $706 \mathrm{~kb}$ in length. This allele, which encodes partitioning defective 3 homolog protein, plays a role in signaling processes involved in both cell division and cell-cell adhesion. 